J Chron Dis 1970, Vol. 23, pp. 161-172. Pergamon Press. Printed in Great Britain

\title{
OBSERVATIONS ON THE DISTRIBUTION OF SERUM URIC ACID LEVELS IN PARTICIPANTS OF THE TECUMSEH, MICHIGAN, COMMUNITY HEALTH STUDIES
}

\section{A COMPARISON OF RESULTS OF ONE METHOD USED AT TWO DIFFERENT TIMES AND OF TWO METHODS USED SIMULTANEOUSLY}

\author{
H. J. DodGe, M.D. \\ Department of Epidemiology, School of Public Health \\ and \\ W. M. MikKelsen, M.D. \\ Department of Internal Medicine, and The Rackham Arthritis Research Unit, Medical School, \\ The University of Michigan, Ann Arbor, Michigan, U.S.A.
}

(Received 13 March 1969; in revised form 12 February 1970)

\section{INTRODUCTION}

IN 1959-1960, approximately 90 per cent of the residents of Tecumseh, Michigan, participated in the Tecumseh Community Health Study by undergoing a comprehensive health examination, in the course of which information was collected regarding certain symptoms, physical findings, and laboratory manifestations of rheumatic diseases. As a part of the examination, serum uric acid (SUA) concentration was determined by an enzymatic spectrophotometric method (ES) [1]. The distribution characteristics of serum uric acid concentrations in this population in the 1959-1960 study (TCHS I) have been reported [2]. In 1962-1965 residents of Tecumseh were invited to participate in a second, similar, series of examinations (TCHS II), which included measurement of serum uric acid by the same technique and, in addition, by an automated colorimetric method (AC) [3]. The purpose of the present report is to compare the serum uric acid distribution statistics in two ways: (1) The comparison of the results of the ES method in those whose sera were tested by this method, both in TCHS I and II; and (2) The comparison of the results in those whose sera were tested by both methods in TCHS II.

\section{METHODS}

All available sera were examined for uric acid content by an enzymatic spectrophotometric (ES) method, reported in an earlier paper [2]. All determinations in the first series of examinations were performed by the same technician; determinations in the second ES series were done almost wholly by a second technician, who was trained by and whose technique was carefully standardized to that of the first tech- 
nician. The determinations made by the second method (AC) in TCHS II sera were done, wholly, by the one technician who had done the ES method in TCHS I.

With the automated colorimetric procedure, the average recovery of urate standard solutions added to control sera over a range of $6-30 \mathrm{mg}$ per $100 \mathrm{ml}$ was 101.2 per cent, as compared with an average recovery of 99.2 per cent with the enzymatic spectrophotometric method. The standard deviations of the methods based on duplicate determinations of 15 sera supplied as coded, unknown, samples was $\pm 0.06 \mathrm{mg}$ per $100 \mathrm{ml}$ for the automated colorimetric method and $\pm 0.25 \mathrm{mg}$ per $100 \mathrm{ml}$ for the enzymatic spectrophotometric method. To ensure quality control, a standard curve was constructed for each group of determinations, using standard urate solutions in concentrations of $2.0,4.0,6.0,8.0,10.0$, and $12.0 \mathrm{mg}$ per $100 \mathrm{ml}$. In addition, commercial control sera (Versatol, Versatol-A and Versatol-A Alternate) in the normouricemic and hyperuricemic ranges were included with each group of assays.

\section{RESULTS}

One method used at two different times

The data are SUA concentrations of 3388 study subjects whose sera were tested by the ES method, both in TCHS I and in TCHS II. Of these, 1663 were male and 1725 were female.

The average interval between tests was calculated on the basis of the stated age at last birthday preceding the tests. The result can be tabulated as follows:

\begin{tabular}{crc}
\hline & \multicolumn{2}{c}{ Subjects } \\
\cline { 2 - 3 } Interval & Number & Percentage \\
\hline 2 & 13 & 0.4 \\
3 & 549 & 16.2 \\
4 & 2030 & 59.9 \\
5 & 734 & 21.7 \\
6 & 62 & 1.8 \\
\hline Total & 3388 & 100.0 \\
\hline
\end{tabular}

The mean of this distribution is $4.1 \mathrm{yr}$, with a standard deviation of $\pm 0.68 \mathrm{yr}$. This rather wide range of interval resulted from a change in the method of calling in participants for examination for TCHS II from that employed in TCHS I. However, 60 per cent had an interval of $4 \mathrm{yr}$ and 98 per cent had an interval ranging from 3 to 5 yr between examinations.

It is to be expected that most individuals tested twice over a considerable interval of time will exhibit a difference between test results. With a biochemical variable, such as SUA, the expected difference: is most likely to be thought of in terms of variability in the testing procedure; some differences can be expected with ageing, particularly with children, adolescent males and postmenopausal women [2]; other changes may occur with change in diet or with drug therapy; while still others represent random variation from many other sources. 
It is, also, to be expected that not all changes in serum uric acid values will be in the same direction or of the same magnitude. In comparison with the results in TCHS I, 3.8 per cent of subjects showed no change in TCHS II, while 40.3 per cent showed a lower value and 55.9 per cent, a higher value. A somewhat greater proportion of males experienced an increase in serum uric acid concentration between TCHS I and II than did females. This is reflected in the change of mean values, where the males experienced an increase of $0.32 \mathrm{mg}$ per $100 \mathrm{ml}$, as compared to 0.18 for females, as shown in Table 1. Since the sex-specific differences between mean values

TABLe 1. AgE-SEX SPECIFIC DIFFERENCES IN SUA(ES) LEVELS BETWEEN TCHS I AND II IN SUBJECTS TESTED IN BOTH STUDIES AT AN AVERAGE INTERVAL OF FOUR YEARS

\begin{tabular}{|c|c|c|c|c|c|c|c|c|}
\hline \multirow{3}{*}{$\begin{array}{l}\text { Age in } \\
\text { years at } \\
\text { TCHS II }\end{array}$} & \multicolumn{4}{|c|}{ Males } & \multicolumn{4}{|c|}{ Females } \\
\hline & \multirow{2}{*}{$\begin{array}{l}\text { Number } \\
\text { of } \\
\text { subjects }\end{array}$} & \multicolumn{3}{|c|}{ Mean SUA(ES)* } & \multirow{2}{*}{$\begin{array}{c}\text { Number } \\
\text { of } \\
\text { subjects }\end{array}$} & \multicolumn{3}{|c|}{ Mean SUA(ES)* } \\
\hline & & TCHS II & TCHS I & Diff. & & TCHS II & TCHS I & Diff. \\
\hline $\begin{array}{c}7-9 \\
10-14 \\
15-19\end{array}$ & $\begin{array}{r}27 \\
217 \\
233\end{array}$ & $\begin{array}{l}3.53 \\
4.38 \\
5.47\end{array}$ & $\begin{array}{l}3.27 \\
3.76 \\
4.61\end{array}$ & $\begin{array}{l}+0.26 \\
+0.62 \\
+0.86\end{array}$ & $\begin{array}{r}36 \\
177 \\
182\end{array}$ & $\begin{array}{l}3.80 \\
4.19 \\
4.21\end{array}$ & $\begin{array}{l}3.57 \\
3.76 \\
4.14\end{array}$ & $\begin{array}{l}+0.23 \\
+0.43 \\
+0.07\end{array}$ \\
\hline $\begin{array}{l}20-24 \\
25-29 \\
30-34\end{array}$ & $\begin{array}{r}85 \\
96 \\
149\end{array}$ & $\begin{array}{l}5.54 \\
5.52 \\
5.41\end{array}$ & $\begin{array}{l}5.31 \\
5.39 \\
5.28\end{array}$ & $\begin{array}{l}+0.23 \\
+0.13 \\
+0.13\end{array}$ & $\begin{array}{r}94 \\
146 \\
166\end{array}$ & $\begin{array}{l}4.17 \\
4.09 \\
4.23\end{array}$ & $\begin{array}{l}4.23 \\
4.00 \\
4.09\end{array}$ & $\begin{array}{l}-0.06 \\
+0.09 \\
+0.14\end{array}$ \\
\hline $\begin{array}{l}35-39 \\
40-44 \\
45-49\end{array}$ & $\begin{array}{l}166 \\
164 \\
148\end{array}$ & $\begin{array}{l}5.38 \\
5.17 \\
5.31\end{array}$ & $\begin{array}{l}5.07 \\
5.14 \\
4.94\end{array}$ & $\begin{array}{l}+0.31 \\
+0.03 \\
+0.37\end{array}$ & $\begin{array}{l}197 \\
175 \\
142\end{array}$ & $\begin{array}{l}4.04 \\
4.31 \\
4.50\end{array}$ & $\begin{array}{l}3.92 \\
4.08 \\
4.33\end{array}$ & $\begin{array}{l}+0.12 \\
+0.23 \\
+0.17\end{array}$ \\
\hline $\begin{array}{l}50-54 \\
55-59 \\
60-64\end{array}$ & $\begin{array}{r}114 \\
87 \\
69\end{array}$ & $\begin{array}{l}5.34 \\
5.23 \\
5.58\end{array}$ & $\begin{array}{l}5.45 \\
5.01 \\
5.60\end{array}$ & $\begin{array}{l}-0.11 \\
+0.22 \\
-0.02\end{array}$ & $\begin{array}{r}105 \\
96 \\
68\end{array}$ & $\begin{array}{l}4.58 \\
4.80 \\
5.10\end{array}$ & $\begin{array}{l}4.36 \\
4.76 \\
4.70\end{array}$ & $\begin{array}{l}+0.22 \\
+0.04 \\
+0.40\end{array}$ \\
\hline $\begin{array}{l}65-69 \\
70-74 \\
75+\end{array}$ & $\begin{array}{l}46 \\
31 \\
31\end{array}$ & $\begin{array}{l}5.36 \\
5.41 \\
5.60\end{array}$ & $\begin{array}{l}5.35 \\
5.17 \\
5.23\end{array}$ & $\begin{array}{l}+0.01 \\
+0.24 \\
+0.37\end{array}$ & $\begin{array}{l}51 \\
42 \\
49\end{array}$ & $\begin{array}{l}4.86 \\
5.13 \\
5.23\end{array}$ & $\begin{array}{l}4.87 \\
4.79 \\
4.56\end{array}$ & $\begin{array}{l}-0.01 \\
+0.34 \\
+0.67\end{array}$ \\
\hline $\begin{array}{l}\text { All ages } \\
\text { observed }\end{array}$ & 1663 & 5.23 & 4.91 & +0.32 & 1725 & 4.36 & 4.18 & +0.18 \\
\hline $\begin{array}{l}\text { Age } \\
\text { adjusted }\end{array}$ & - & 5.25 & 4.94 & +0.31 & - & 4.36 & 4.18 & +0.18 \\
\hline
\end{tabular}

*In mg per $100 \mathrm{ml}$.

Note: TCHS II = examination in 1962-1965.

TCHS I = examination in 1956-1960.

Diff. = TCHS II minus TCHS I.

may be, in part, due to differences in the age distributions of the two sexes, age adjusted mean SUA values were calculated. For the values in Table 1, adjustment makes for only a negligible difference.

The changes in age specific mean SUA(ES) are best seen in Fig. 1. Here, the two sets of curves, male and female, are of the expected shape [2]. The greater degrees of increase are seen in the younger males in the age range of 10 to 19 years; thereafter, 


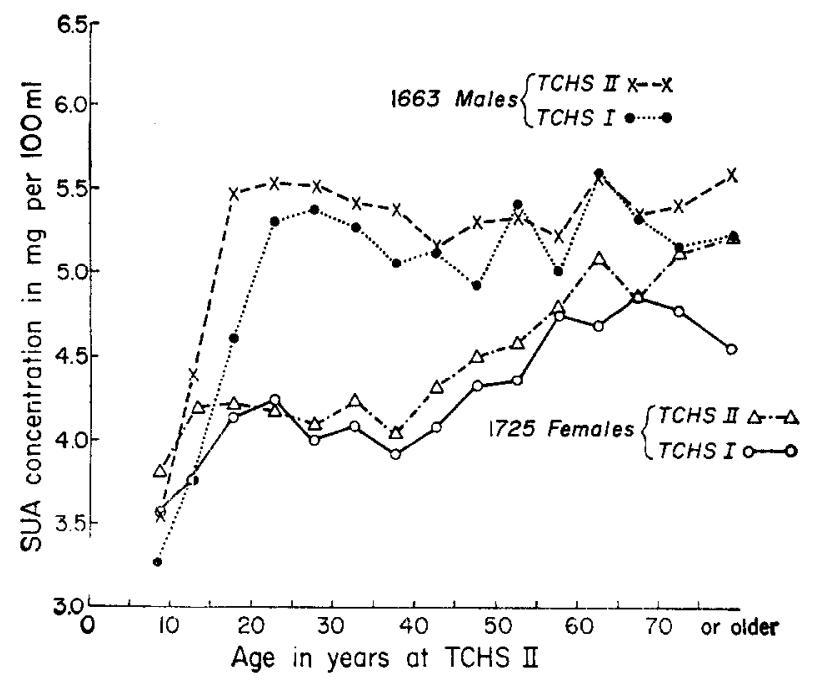

Fig. 1. Age-sex specific mean serum uric acid levels, determined by an enzymatic spectrophotometric method, of participants whose sera were tested both in 1958-1960 and in 1962-1965, Tecumseh Community Health Study.

no consistent pattern of difference is to be seen. Among female subjects, there is considerable increase in the age range 7-14, as expected, very little change in the age range 15-39, but a gradually increasing magnitude of difference through the remainder of the age range covered, with the single exception of the age range 65-69 yr. The final plotting point is made at $79 \mathrm{yr}$, since that is the median age for all persons $75 \mathrm{yr}$ or older whose SUA values contributed to these means. The same will be true of Fig. 2.

TABLE 2. SEX SPECIFIC DISTRIBUTION* OF THE NATURE OF SUA(ES) DIFFERENCES BETWEEN TCHS I AND TCHS II VALUES

\begin{tabular}{|c|c|c|c|c|}
\hline \multirow[b]{2}{*}{ Sex } & \multirow[b]{2}{*}{ Nature of difference } & \multicolumn{2}{|c|}{ Subjects } & \multirow{2}{*}{$\begin{array}{c}\text { Maximum } \\
\text { difference } \\
(\mathrm{mg} \text { per } 100 \mathrm{ml})\end{array}$} \\
\hline & & Number & $\begin{array}{l}\text { Percentage } \\
\text { of total }\end{array}$ & \\
\hline \multirow[t]{2}{*}{ Male } & $\begin{array}{l}\text { No difference } \\
\text { ES I greater than ES II } \\
\text { ES II greater than ES I }\end{array}$ & $\begin{array}{r}63 \\
652 \\
948\end{array}$ & $\begin{array}{r}3.8 \\
39.2 \\
57.0\end{array}$ & $\begin{array}{l}\overline{5.9} \\
9.9\end{array}$ \\
\hline & Total & 1663 & 100.0 & - \\
\hline \multirow[t]{2}{*}{ Female } & $\begin{array}{l}\text { No difference } \\
\text { ES I greater than ES II } \\
\text { ES II greater than ES I }\end{array}$ & $\begin{array}{r}65 \\
712 \\
948\end{array}$ & $\begin{array}{r}3.8 \\
41.3 \\
54.9\end{array}$ & $\begin{array}{l}\overline{8.2} \\
5.6\end{array}$ \\
\hline & Total & 1725 & 100.0 & - \\
\hline
\end{tabular}

- Difference between the two distributions is not statistically significant $\left(\chi^{2}=1.571\right.$; d.f. $=2$; $p=0.50)$. 


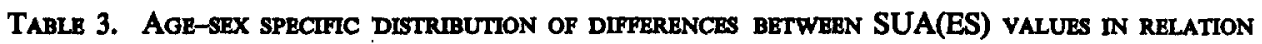
TO MAGNITUDE AND DIRECTION OF THE DIFFERENCE TCHS I AND II

\begin{tabular}{|c|c|c|c|c|c|}
\hline \multirow[b]{2}{*}{$\begin{array}{c}\text { Age group } \\
\text { (yr) }\end{array}$} & \multirow{2}{*}{$\begin{array}{c}\text { Magnitude } \\
\text { of } \\
\text { difference } \\
\text { (mg per } 100 \mathrm{ml} \text { ) }\end{array}$} & \multicolumn{2}{|c|}{ I greater than II } & \multicolumn{2}{|c|}{ II greater than I } \\
\hline & & Number & $\begin{array}{l}\text { Percentage } \\
\text { of total }\end{array}$ & Number & $\begin{array}{l}\text { Percentage } \\
\text { of total }\end{array}$ \\
\hline \multicolumn{6}{|c|}{ Males } \\
\hline \multirow[t]{2}{*}{$7-19$} & $\begin{array}{l}0.1-0.9 \\
1.0-1.9 \\
2.0 \text { or more }\end{array}$ & $\begin{array}{l}74 \\
33 \\
16\end{array}$ & $\begin{array}{l}60.2 \\
26.8 \\
13.0\end{array}$ & $\begin{array}{r}129 \\
135 \\
73\end{array}$ & $\begin{array}{l}38.3 \\
40.0 \\
21.7\end{array}$ \\
\hline & Total & 123 & 100.0 & 337 & 100.0 \\
\hline \multirow[t]{2}{*}{$20-39$} & $\begin{array}{l}0.1-0.9 \\
1.0-1.9 \\
2.0 \text { or more }\end{array}$ & $\begin{array}{r}145 \\
55 \\
17\end{array}$ & $\begin{array}{r}66.8 \\
25.4 \\
7.8\end{array}$ & $\begin{array}{r}155 \\
66 \\
43\end{array}$ & $\begin{array}{l}58.7 \\
25.0 \\
16.3\end{array}$ \\
\hline & Total & 217 & 100.0 & 264 & 100.0 \\
\hline \multirow[t]{2}{*}{$40-59$} & $\begin{array}{l}0.1-0.9 \\
1.0-1.9 \\
2.0 \text { or more }\end{array}$ & $\begin{array}{r}147 \\
62 \\
27\end{array}$ & $\begin{array}{l}62.3 \\
26.3 \\
11.4\end{array}$ & $\begin{array}{r}148 \\
73 \\
36\end{array}$ & $\begin{array}{l}57.6 \\
28.4 \\
14.0\end{array}$ \\
\hline & Total & 236 & 100.0 & 257 & 100.0 \\
\hline \multirow[t]{2}{*}{60 or more } & $\begin{array}{l}0.1-0.9 \\
1.0-1.9 \\
2.0 \text { or more }\end{array}$ & $\begin{array}{l}40 \\
24 \\
12\end{array}$ & $\begin{array}{l}52.6 \\
31.6 \\
15.8\end{array}$ & $\begin{array}{l}50 \\
25 \\
15\end{array}$ & $\begin{array}{l}55.5 \\
27.8 \\
16.7\end{array}$ \\
\hline & Total & 76 & 100.0 & 90 & 100.0 \\
\hline
\end{tabular}

Females

\begin{tabular}{|c|c|c|c|c|c|}
\hline \multirow[t]{2}{*}{$7-19$} & $\begin{array}{l}0.1-0.9 \\
1.0-1.9 \\
2.0 \text { or more }\end{array}$ & $\begin{array}{r}105 \\
39 \\
11\end{array}$ & $\begin{array}{r}67.7 \\
25.2 \\
7.1\end{array}$ & $\begin{array}{r}131 \\
74 \\
22\end{array}$ & $\begin{array}{r}57.7 \\
32.6 \\
9.7\end{array}$ \\
\hline & Total & 155 & 100.0 & 227 & 100.0 \\
\hline \multirow[t]{2}{*}{$20-39$} & $\begin{array}{l}0.1-0.9 \\
1.0-1.9 \\
2.0 \text { or more }\end{array}$ & $\begin{array}{r}190 \\
55 \\
22\end{array}$ & $\begin{array}{r}71.2 \\
20.6 \\
8.2\end{array}$ & $\begin{array}{r}205 \\
77 \\
29\end{array}$ & $\begin{array}{r}65.9 \\
24.8 \\
9.3\end{array}$ \\
\hline & Total & 267 & 100.0 & 311 & 100.0 \\
\hline \multirow[t]{2}{*}{$40-59$} & $\begin{array}{l}0.1-0.9 \\
1.0-1.9 \\
2.0 \text { or more }\end{array}$ & $\begin{array}{r}132 \\
57 \\
16\end{array}$ & $\begin{array}{r}64.4 \\
27.8 \\
7.8\end{array}$ & $\begin{array}{r}184 \\
84 \\
25\end{array}$ & $\begin{array}{r}62.8 \\
28.7 \\
8.5\end{array}$ \\
\hline & Total & 205 & 100.0 & 293 & 100.0 \\
\hline \multirow[t]{2}{*}{60 or more } & $\begin{array}{l}0.1-0.9 \\
1.0-1.9 \\
2.0 \text { or more }\end{array}$ & $\begin{array}{l}50 \\
24 \\
11\end{array}$ & $\begin{array}{l}58.9 \\
28.2 \\
12.9\end{array}$ & $\begin{array}{l}56 \\
32 \\
29\end{array}$ & $\begin{array}{l}47.9 \\
27.3 \\
24.8\end{array}$ \\
\hline & Total & 85 & 100.0 & 117 & 100.0 \\
\hline
\end{tabular}


The differences in patterns seen in Fig. 1 are certainly consistent with what we know of the changes in SUA(ES) with age, for each sex. These patterns, however, represent the average behaviour of SUA(ES) change. The changes within individual subjects are quite another matter, as will be summarized in Table 2. Table 2 shows that a greater proportion of females had an apparent decrease in SUA(ES) values, as well as a lesser magnitude of change (whether increase or decrease) than did males. The maximum change in individual study subjects was a decrease of 5.9 and an increase of $9.9 \mathrm{mg}$ per $100 \mathrm{ml}$ for males, with 8.2 and 5.6 , respectively, for females.

Since Table 1 and Fig. 1 showed some large increments in mean SUA(ES) between TCHS I and TCHS II, Table 3 was constructed to show the distribution of increments or decrements, in mg per $100 \mathrm{ml}$, for each sex and four age groups.

The four age groups were chosen after consideration of Table 1 and Fig. 1 . In age group 7-19 yr there is a considerable rise in SUA(ES) values, especially with the males. In age group 20-39 yr the values tend to plateau, especially for the females. In age group 40-59 yr, the values for males tend to vary about the value of $5.25 \mathrm{mg}$ per $100 \mathrm{ml}$, while the females show a steady rise. In age group $60 \mathrm{yr}$ or more the means for both sexes are quite variable and show no particular pattern.

Whether one looks at decrements (TCHS I greater than TCHS II), it is evident that males had decrements of 2.0 or more $\mathrm{mg}$ per $100 \mathrm{ml}$ more frequently than did females except for age group 20-39 yr, or whether one looks at increments (TCHS II greater than TCHS I), the same thing is true except for age group 60 or more years. The remainder of the data follow the pattern suggested by Table 2 .

Although the differences in SUA(ES) of the individual participants have not yet been correlated with the clinical records, it is of some interest to ascertain how these changes would effect the individual's status as to classification in terms of 'normouricemic' or 'hyperuricemic'. Since we have customarily used $7.0 \mathrm{mg}$ per $100 \mathrm{ml}$ for males and 6.0 for females, as the cutting point to divide hyperuricemia from normouricemia in our studies, it is possible to estimate the number of individuals whose status would change as a result of the differences between two SUA(ES) determinations over an average of $4 \mathrm{yr}$ interval of time.

From the evidence available in the present study, it can be shown that for those whose SUA (ES) levels changed, there would be the following change in classification as to 'hyper'- or 'normo'-uricemia:

\begin{tabular}{|c|c|c|}
\hline \multirow[b]{2}{*}{ Status as to uricemia } & \multicolumn{2}{|c|}{ Number of subjects } \\
\hline & Male & Female \\
\hline Remain 'hyper' & 29 & 32 \\
\hline From 'hyper' to 'normo' & 90 & 88 \\
\hline From 'normo' to 'hyper' & 109 & 102 \\
\hline Remain 'normo' & 1372 & 1438 \\
\hline Total & 1600 & 1660 \\
\hline
\end{tabular}

This would indicate a net addition of 19 males and 14 females to the hyperuricemic class. 


\section{Two methods used at the same time}

The data are the SUA concentrations of 4196 study subjects whose sera from TCHS II were tested by both the enzymatic spectrophotometric and the automated colorimetric methods; of this total, 2092, or 49.9 per cent, were male subjects and 2104, or 50.1 per cent, were female.

Although not illustrated here, the distributions of SUA concentrations for each sex and each method are of the bell-shaped curve type with a slight degree of skewing toward the high SUA values and very similar to those previously published for TCHS I [2]. The curves for each sex are of the same general shape for each of the methods used in TCHS II; the only essential difference is that the curves for SUA(AC) are rather consistently shifted to the higher values in the scale of SUA concentrations than are the curves for SUA(ES). The two curves for female subjects more nearly conform to one another than do the two curves for male subjects.

Comparison of the sex-age specific mean SUA values for the 4196 participants

TABLE 4. AGE-SEX SPECIFIC MEAN SERUM URIC ACID VALUES AND THEIR DIFFERENCES, IN PARTICIPANTS TESTED BY BOTH METHODS, TCHS II, 1962-1965

\begin{tabular}{|c|c|c|c|c|c|c|c|c|}
\hline \multirow{3}{*}{$\begin{array}{l}\text { Age in } \\
\text { years }\end{array}$} & \multicolumn{4}{|c|}{ Males } & \multicolumn{4}{|c|}{ Females } \\
\hline & \multirow{2}{*}{$\begin{array}{l}\text { Number } \\
\text { of } \\
\text { subjects }\end{array}$} & \multicolumn{3}{|c|}{ SUA means* } & \multirow{2}{*}{$\begin{array}{l}\text { Number } \\
\text { of } \\
\text { subjects }\end{array}$} & \multicolumn{3}{|c|}{ SUA means* } \\
\hline & & $\mathrm{AC}$ & ES & Diff. & & $\mathrm{AC}$ & ES & Diff. \\
\hline $0-4$ & 6 & 3.00 & 3.17 & -0.17 & 6 & 3.18 & 3.67 & -0.49 \\
\hline $5-9$ & 204 & 3.75 & 3.69 & +0.06 & 191 & 3.87 & 3.81 & +0.06 \\
\hline $10-14$ & 312 & 4.46 & 4.29 & +0.17 & 263 & 4.31 & 4.14 & +0.17 \\
\hline $15-19$ & 258 & 5.78 & 5.57 & +0.21 & 214 & 4.37 & 4.27 & +0.10 \\
\hline $20-24$ & 143 & 5.94 & 5.73 & +0.21 & 176 & 4.25 & 4.16 & +0.09 \\
\hline $25-29$ & 142 & 5.93 & 5.71 & +0.22 & 167 & 4.52 & 4.32 & +0.20 \\
\hline $30-34$ & 167 & 5.76 & 5.54 & +0.22 & 184 & 4.38 & 4.30 & +0.08 \\
\hline $35-39$ & 182 & 5.81 & 5.57 & +0.24 & 221 & 4.29 & 4.09 & +0.20 \\
\hline $40-44$ & 188 & 5.54 & 5.36 & +0.18 & 173 & 4.50 & 4.40 & +0.10 \\
\hline $45-49$ & 138 & 5.71 & 5.57 & +0.14 & 135 & 4.59 & 4.49 & +0.10 \\
\hline $50-54$ & 106 & 5.62 & 5.23 & +0.39 & 94 & 4.91 & 4.47 & +0.17 \\
\hline $55-59$ & 83 & 5.75 & 5.56 & +0.19 & 85 & 5.08 & 4.84 & +0.24 \\
\hline $60-64$ & 62 & 5.84 & 5.53 & +0.31 & 64 & 5.29 & 5.08 & +0.21 \\
\hline $65-69$ & 43 & 5.86 & 5.49 & +0.37 & 53 & 5.12 & 4.92 & $\begin{array}{r}+0.20 \\
\end{array}$ \\
\hline $70-74$ & 32 & 6.05 & 5.60 & +0.45 & 42 & 5.46 & 5.15 & +0.31 \\
\hline $75+$ & 26 & 6.08 & 5.95 & +0.13 & 36 & 5.40 & 5.15 & +0.25 \\
\hline $\begin{array}{l}\text { All ages } \\
\text { observed }\end{array}$ & 2092 & 5.38 & 5.17 & +0.21 & 2104 & 4.47 & 4.33 & +0.14 \\
\hline Age & & & & & & & & \\
\hline adjusted & - & 5.40 & 5.20 & +0.20 & - & 4.42 & 4.31 & +0.11 \\
\hline
\end{tabular}

* In mg per $100 \mathrm{ml}$.

Note: $\mathrm{AC}=$ automated colorimetric method.

ES = enzymatic spectrophotometric method.

Diff. $=$ SUA(AC) minus SUA(ES). 
who had determinations by both procedures, allows for a more precise estimate of the differences between methods. The curves derived from Table 4, and shown in Fig. 2, are similar; the differences are quite small and, generally, consistent in pattern. The differences were tested by the method of the ratio of the mean difference to its standard error and found to be statistically significant $(P$ less than 0.05$)$ in every specified age-sex group. In general, taking subjects grouped by sex and age, the two methods show remarkable similarity in pattern, with the SUA(AC) method consistently giving slightly higher results than the SUA(ES), barring the youngest age group.

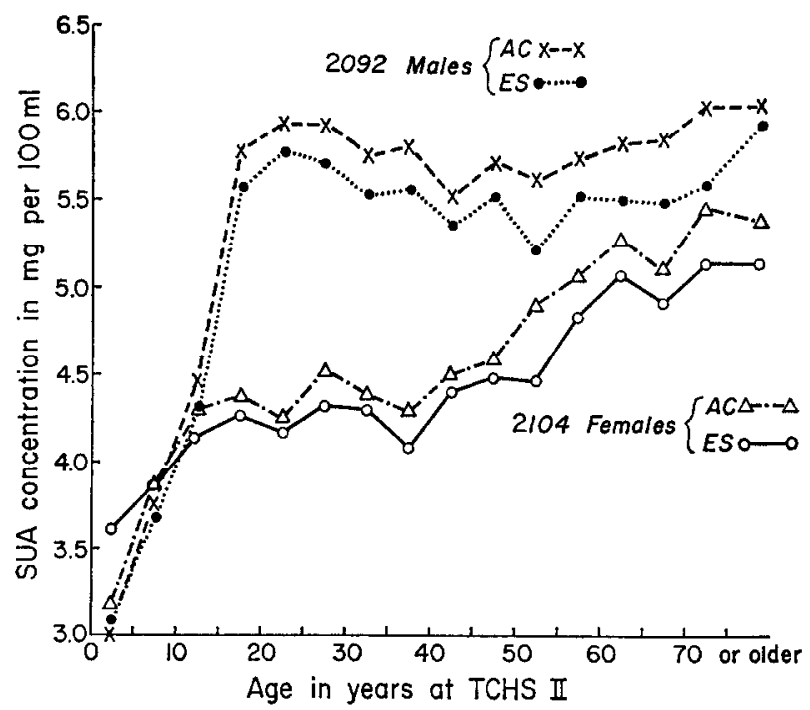

Frg. 2. Age-sex specific mean serum uric acid levels of participants whose sera were tested both by an enzymatic spectrophotometric and an automated colorimetric method in 1962-1965 Tecumseh Community Health Study.

Another aspect of the comparison of the two methods is the difference between results in the individual participants. These differences are summarized in Table 5.

From these data, it will be seen that among the 2092 males, 645 , or 30.8 per cent, had AC method values less than those of ES method, and 1303 or 62.3 per cent had higher AC than ES values; the respective proportions for the 2104 female subjects were 33.2 and 57.8 per cent. It will also be seen, from Table 5 , that the magnitude of the differences tends to be greater among male than among female subjects.

Table 6 is included as an analogy to Table 3, but since the tests were done simultaneously there is no question of ageing as a consideration for differences in SUA values, and no age breakdown is given. The two distributions in Table 6 are very much alike and again it is noted that males have a slightly higher proportion of differences of 2.0 or more $\mathrm{mg}$ per $100 \mathrm{ml}$ than do females.

In considering the clinical significance of the difference between the two tests, it is important to determine how the difference influcnces the classification of the individual as hyperuricemic or normouricemic. The conventional upper normal limit of SUA concentration may again be set at $7.0 \mathrm{mg}$ per $100 \mathrm{ml}$ for males and at 6.0 for 


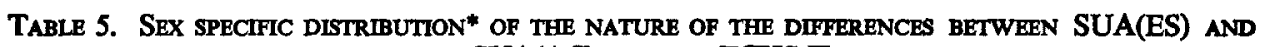
SUA(AC) VALUES. TCHS II

\begin{tabular}{|c|c|c|c|c|}
\hline \multirow[b]{2}{*}{$\operatorname{Sex}$} & \multirow[b]{2}{*}{ Nature of difference } & \multicolumn{2}{|c|}{ Subjects } & \multirow{2}{*}{$\begin{array}{c}\text { Maximum } \\
\text { Difference } \\
\text { (mg per } 100 \mathrm{ml} \text { ) }\end{array}$} \\
\hline & & Number & $\begin{array}{c}\text { Percentage } \\
\text { of total }\end{array}$ & \\
\hline \multirow[t]{2}{*}{ Males } & $\begin{array}{l}\text { No difference } \\
\text { ES greater than AC } \\
\text { AC greater than ES }\end{array}$ & $\begin{array}{r}144 \\
645 \\
1303\end{array}$ & $\begin{array}{r}6.9 \\
30.8 \\
62.3\end{array}$ & $\begin{array}{l}\overline{4.6} \\
6.4\end{array}$ \\
\hline & Total & 2092 & 100.0 & - \\
\hline \multirow[t]{2}{*}{ Females } & $\begin{array}{l}\text { No difference } \\
\text { ES greater than AC } \\
\text { AC greater than ES }\end{array}$ & $\begin{array}{r}190 \\
699 \\
1215\end{array}$ & $\begin{array}{r}9.0 \\
33.2 \\
57.8\end{array}$ & $\begin{array}{l}\overline{7.3} \\
4.4\end{array}$ \\
\hline & Total & 2104 & 100.0 & - \\
\hline
\end{tabular}

* Differences between the two distributions are highly significant statistically $\left(\chi^{2}=11.544 ;\right.$ d.f. $=2$; $P$ is less than 0.01).

TABLE 6. SEX SPECIFIC DISTRIBUTION OF DIFFERENCES BETWEeN SUA (ES) AND SUA (AC) VALUES IN INDIVIDUAL STUDY SUBJECTS. TCHS II

\begin{tabular}{|c|c|c|c|c|c|}
\hline \multirow[b]{2}{*}{ Sex } & \multirow[b]{2}{*}{$\begin{array}{c}\text { Magnitude } \\
\text { of } \\
\text { Difference } \\
\text { (mg per } 100 \mathrm{ml} \text { ) }\end{array}$} & \multicolumn{2}{|c|}{ ES greater than $\mathrm{AC}$} & \multicolumn{2}{|c|}{ AC greater than ES } \\
\hline & & $\begin{array}{c}\text { Number } \\
\text { of } \\
\text { Subjects }\end{array}$ & $\begin{array}{c}\text { Percent } \\
\text { of } \\
\text { total }\end{array}$ & $\begin{array}{c}\text { Number } \\
\text { of } \\
\text { subjects }\end{array}$ & $\begin{array}{c}\text { Percent } \\
\text { of } \\
\text { total }\end{array}$ \\
\hline Male & $\begin{array}{l}\text { Total } \\
0.1-0.9 \\
1.0-1.9 \\
2.0 \text { or more }\end{array}$ & $\begin{array}{r}645 \\
577 \\
56 \\
12\end{array}$ & $\begin{array}{r}100.0 \\
89.3 \\
8.8 \\
1.9\end{array}$ & $\begin{array}{r}1303 \\
1125 \\
143 \\
35\end{array}$ & $\begin{array}{r}100.0 \\
86.2 \\
11.0 \\
2.8\end{array}$ \\
\hline Female & $\begin{array}{l}\text { Total } \\
0.1-0.9 \\
1.0-1.9 \\
2.0 \text { or more }\end{array}$ & $\begin{array}{r}699 \\
647 \\
40 \\
12\end{array}$ & $\begin{array}{r}100.0 \\
92.7 \\
5.7 \\
1.6\end{array}$ & $\begin{array}{r}1215 \\
1095 \\
92 \\
28\end{array}$ & $\begin{array}{r}100.0 \\
90.1 \\
7.6 \\
2.3\end{array}$ \\
\hline
\end{tabular}

females. Using the ES values as a standard, it can be shown that substitution of the $A C$ values would have the following effect:

\begin{tabular}{|c|c|c|}
\hline \multirow[b]{2}{*}{ Classification as to uricemia } & \multicolumn{2}{|c|}{ Number of subjects } \\
\hline & Male & Female \\
\hline Remain 'hyper' & 145 & 117 \\
\hline From 'hyper' to 'normo' & 43 & 31 \\
\hline From 'normo' to 'hyper' & 91 & 71 \\
\hline Remain 'normo' & 1669 & 1695 \\
\hline Total & 1948 & 1914 \\
\hline
\end{tabular}

There would be a net gain of 48 males and 40 females to the hyperuricemic class. 


\section{DISCUSSION}

All of the sex-age specific mean serum uric acid curves, here reported, are of the same general shape. This gives us increased confidence in the essential validity of the curves already published, which they closely resemble [2].

For those study participants who had SUA(ES) determination, both in 1958-1960 and 1962-1965, there was an overall average increase of $0.32 \mathrm{mg}$ per $100 \mathrm{ml}$ for males, and 0.18 for females in the average interval of $4.1 \mathrm{yr}$ between observations. The sex-age specific mean SUA(ES) curves clearly show the average differences.

The reasons for the age-sex specific mean SUA(ES) differences at two points in time offer interesting material for speculation. That there is a prominent ageing factor is indisputable in terms of males in the age range of 7-19 $\mathrm{yr}$. When the three age groups, 7-9, 10-14 and 15-19 yr, which are suggested by Fig. 1 as having a rather steady increase in mean SUA(ES), are deleted from Table 1, the differences between the TCHS II and I means of SUA for the remainder of the age groups ( $20 \mathrm{yr}$ or older) becomes +0.17 for males and +0.15 for females, a negligible sex difference. When the differences between means for TCHS II and TCHS I for each of the other age groups (20-24 through 75+ yr) are examined, they suggest that, for age $20 \mathrm{yr}$ and over, differences between means for the individual age groups in relation to time are simply random variation about their common mean (except, perhaps, females $75 \mathrm{yr}+$ ) and not essentially due to ageing.

The factor that suggests itself most prominently as cause for most of the differences is in the technique of determining SUA(ES) for the two time periods, despite careful standardization of the two technicians at the outset of the TCHS II determinations.

We are not aware of any radical or wholesale change in the diet of the residents of the community that might produce an average increase in SUA. Nor have we been able to assess the nature of therapy that might inhibit or enhance the excretion of serum urate. Misidentification of the individual must be considered a possiblity. All of these factors, however, are probably randomly distributed and are inconsequential in determining the magnitude of the age-sex specific means.

The average changes in SUA(ES), shown in Fig. 1, do not reflect the entire picture. Perhaps, the most interesting observations concern the changes between SUA(ES) levels in individual study subjects. Although most of the changes, whether negative or positive, tend to be small, 11.3 per cent of males, and 8.3 per cent of females, showed a decrease of 2.0 or more $\mathrm{mg}$ per $100 \mathrm{ml}$, and the respective figures for an increase of the same order were 17.4 per cent and 11.1 per cent.

Change of 2.0 or more $\mathrm{mg}$ per $100 \mathrm{ml}$ must be considered large in relation to a scale of measurement in which the mean and the upper limit of normal are, generally, considered to be 5.0 and $7.0 \mathrm{mg}$ per $100 \mathrm{ml}$ for male, and 4.0 and 6.0 for female, subjects. Some of the changes are, however, enormous in relation to the measurement scale employed. Decreases of as much as 8.2 , and increases of as much as $9.9 \mathrm{mg}$ per $100 \mathrm{ml}$ were observed; such large differences as these latter can reasonably be attributed only to technical factors or to misidentification of the study subject.

It is evident that there is a striking similarity between the results of determination of SUA values when done by the automated colorimetric method and by the enzymatic spectrophotometric method in this population study. The patterns of the mean SUA values, specified for sex and age, show a remarkable similarity in shape.

It is also evident that the results of SUA determination by the AC method are 
slightly and consistently, except for the age group 0-4 yr, higher than those of the ES method. In the one exceptional age group, ES values are greater than, or equal to, $A C$ values except for one individual subject. While the AC method gives results, which are, on the average, only slightly higher than the ES results, the difference is, nonetheless, statistically significant in relation to the magnitude of numbers of subjects considered here.

More serious concerns arise when the individual study subject is considered. The difference between results of the two tests, done simultaneously on the same individual's serum, vary as much as $4.4 \mathrm{mg}$ per $100 \mathrm{ml}$ increase, and 7.3 decrease, when AC values are substituted for ES values. At the moment, how much of this variation can be attributed to fundamental differences in what is being measured by the tests, to technical error, or to misidentification cannot be stated, but does make for concern.

Many of the differences between the results of the two methods, in fact the large majority, make little practical difference. They do not change the individual's classification as to hyperuricemia or normouricemia. It is a matter of concern, however, that the differences between test results that leave 236 , or 5.6 per cent of participating subjects in an ambiguous position as to such a classification in this population study.

While it possesses the theoretical advantage of greater specificity than colorimetric procedures, the manual performance of SUA determinations by the enzymatic spectrophotometric method is time consuming and tedious and not necessarily associated with greater accuracy or reproducibility. Since it appears, on the basis of this experience, to provide essentially the same information, the automated colorimetric method possesses the advantages for population studies of greater technical simplicity, less time consumption, and reduced cost. These advantages may become less significant if automation of the enzymatic spectrophotometric procedure can be achieved.

One of our major concerns is that of difference between the SUA values of an individual (whether, with a single method repeated over time, or with two methods used on the same serum) and the individual's position relative to a stated 'upper limit of normal'. SUA concentration is an important criterion in the differential diagnosis of joint disease and serum urate is a biochemical substance whose concentration distribution is that of an apparently continuously distributed variable. More mathematical research, such as that of Frankowski [4] and of Murphy and Abbey [5], is needed to provide more specific and precise methods of resolving a continuous curve of distribution into its normal and abnormal components. Though it is not likely that such method will provide an absolute standard for distinguishing between clinically significant and non-significant levels of serum uric acid, the investigator and the clinician should know what proportion of 'false positives', and of 'false negatives', are associated with any particular cutting point value.

\section{SUMMARY}

Individuals participating in the Tecumseh Community Health Study, in 1959-1960 (TCHS I) and 1962-1965 (TCHS II), had serum uric acid determinations by an enzymatic spectrophotometric method, SUA(ES), as part of a comprehensive health examination.

Among the 1633 male and 1725 female subjects, the mean serum uric acid concentra- 
tion had increased by $0.32 \mathrm{mg}$ per $100 \mathrm{ml}$ for males, and by 0.18 for females, over the the average of $4.1 \mathrm{yr}$ between determinations. It was found that, approximately, 40 per cent of subjects had a decrease, and 56 per cent, an increase, in serum uric acid concentration. The change was greater than plus or minus $2.0 \mathrm{mg}$ per $100 \mathrm{ml}$ for 28.7 per cent of males and 19.4 per cent of females. Decreases of as much as 8.2, and increases of as much as $9.9 \mathrm{mg}$ per $100 \mathrm{ml}$ were observed. How much of the average increase, in an average $4.1 \mathrm{yr}$ interval between tests, is due to ageing, except for males in the age range of $10-19 \mathrm{yr}$, is problematical. It seems probably that most of the average increase was due to technical factors in performance of the test.

In the study of 1962-1965, serum uric acid determinations were done by two methods. An automated colorimetric method was compared with an enzymatic spectrophotometric method. Both methods showed the same types of distribution curves of serum uric acid concentrations and curves of age-sex specific mean serum uric acid.

The values obtained by the automated colorimetric method were slightly, but, consistently, higher to a statistically significant degree than those of the enzymatic spectrophotometric method.

For 2092 male subjects, the mean SUA(AC) was $0.21 \mathrm{mg}$ per $100 \mathrm{ml}$ greater than the mean SUA(ES), while for 2104 females subjects, this difference was 0.14.

Of 4196 study subjects, whose sera were tested by both methods, about 90.0 per cent showed an agreement of the two values within $\pm 0.9 \mathrm{mg}$ per $100 \mathrm{ml}$. However, 1.9 per cent of males and 1.6 per cent of females, had ES values which exceeded AC values by $2.0 \mathrm{mg}$ per $100 \mathrm{ml}$, while 2.8 per cent of male and 2.3 per cent of female subjects had AC values greater than ES values by $2.0 \mathrm{mg}$ per $100 \mathrm{ml}$. The extremes of differences range from 4.4 to $7.3 \mathrm{mg}$ per $100 \mathrm{ml}$.

The data in this paper gives us increased confidence in the essential validity of the mean age and sex distributions of serum uric acid values, from the Tecumseh Community Health Studies, published in an earlier paper [2].

It is concluded that, for the purposes of population studies, the automated colorimetric method is more advantageous than the enzymatic spectrophotometric method, because of its lesser cost.

Comparison of the results of the two studies emphasizes the problems of definition of hyperuricemia. Further mathematical analysis of the distribution curves obtained in such studies may lead to definitions of normo- and hyperuricemia of greater precision for clinical purposes.

Acknowledgements-This study was supported by Program Project Grant HE 6378 to The Cardiovascular Research Center, The University of Michigan (Thomas Francis, Jr., M.D., Director) from The National Heart Institute, National Institutes of Health and by Grant C.D.-00005 from The U.S. Public Health Service. It is reported for the Research Staff of the Tecumseh, Michigan, Community Health Study.

\section{REFERENCES}

1. Liddle L, Seegmiller JE, Laster L: The enzymatic spectrophotometric method for determination of serum uric acid. J Lab Clin Med 54: 903-913, 1959

2. Mikkelsen WM, Dodge HJ, Valkenburg H: The distribution of serum uric acid values in a population unselected as to gout or hyperuricemia. Amer J Med 39: 242-251, 1965

3. Technical Bulletin, Method N-A13, Technicon Instruments Corp., Chauncy, N.Y.

4. Frankowski RF: Estimation of parameters of Gaussian distributions with application to the distribution of serum uric acid in man. Unpublished dissertation for the Ph.D. degree, The University of Michigan, 1967

5. Murphy EA, Abbey H: The normal range-a common misuse. J Chron Dis 20: 79-88, 1967 